Matematikai Közlemények

V. kötet, 2017

doi:10.20312/dim.2017.08

\title{
50 év biomatematika az agráriumban
}

\author{
Bán István \\ ny. erdőmérnök és alk. matematikus, c. egyetemi docens \\ istvan.ban.dr@gmail.com
}

\begin{abstract}
ÖSSZEFOGLALÓ. Az 1960 óta végzett biomatematikai munkámat mutatom be. Elöször a biomatematika definícióját adtam meg. Ezt követően új biomatematikai módszereket és azok gyakorlati alkalmazását fejlesztettem ki. Nevezetesen ez a cikk az erdőgazdálkodás, növénytermesztés és vadgazdálkodás problémáinak biomatematikai megoldásaival foglalkozik. Ezek a megoldások tartalmazzák a biomatematikai fejlesztésnek, állapotjellemzők hatásmechanizmusainak és erdészeti hozamszabályozásnak, valamint növénytermesztési szaktanácsadásnak az alkalmazását.
\end{abstract}

\begin{abstract}
I am presenting my biomathematical work since 1960. First, I developed a definition of biomathematics. Then, I developed some new biomathematical methods and their practical applications. Accordingly, this paper deals with biomathematical solutions to forest management, plant cultivation and game management problems. These solutions involve the application of biomathematical research, state characteristics effect mechanisms and forest yield regulation as well as providing plant cultivation expert consultancy.
\end{abstract}

\section{Bevezetés}

A második világháborút követő felpörgött szellemi életben született meg tudtommal az első biomatematika írás [1]. Rá pár évre kezdtem el foglalkozni ezzel a tudományterülettel [2]. Egy évtized múlva Dala László főszerkesztő Úr felkérésére Rényi Alfréd lektorálásával megírt cikkemben definiáltam a biomatematika fogalmát [3]. Dr. Sós Gábor földmüvelésügyi államtitkár, Dr. Madas András tervhivatali államtitkár, Dr. Sali Emil erdészeti hivatalvezető és Dr. Nagy Bálint agrokémiai főosztályvezető felismerve e tárgyban rejlő lehetőségeket a Fővárosi Növényvédő Állomás keretei között 1968-ban létrehozták a „Biomatematika csoportot”, amelynek vezetésével engem bíztak meg. Ezt követően végig fejlesztőmérnökként és -matematikusként dolgoztam.

Az agráriumon belül az agrokémiai-, erdészeti-, növénytermesztési és vadgazdálkodási feladatok biomatematikai megoldására koncentráltam. Munkám határterületeként távészlelés, azaz remote sensing és biofizikai módszereket is fejlesztettem, illetve alkalmaztam.

A megoldandó gyakorlati feladatok sokrétüsége változatos matematikai apparátust igényelt. A biomatematikában egyrészt felhasználtam a rendelkezésemre álló matematikai konstrukciókat egy adott biológiai feladat megoldására, másrészt pedig ami lényeges különbség, hogy maga a biológiai objektum sajátosságai definiálták a matematikai konstrukciókat [3]. A gyakorlatban ezt a kettősséget nem kellett mereven szétválasztani, sőt, azok sok esetben összemosódtak. 


\section{Feladatok tárgyalása}

A természetes- és kultúrnövény állapot felmérésére alkalmas ortofotoszkópiában a fokális (szögtartó) pontra alapozott új képalkotási képleteket dolgoztam ki Dr. Bezzegh László Kossuth-díjas egy. tanár Úr részére, amelyek nagyban elősegítették kiértékelő műszerének tervezését, és számítógépes megoldását.

A megfigyelt biológiai objektum helyét kellett meghatároznom klasszikus trigonometriával legalább három ismert koordinátájú pontra mért csapásszögek segítségével, vagy ismert koordinátájú, legalább három pontból a meghatározandó pontra mért csapásszögekkel, különös tekintettel a fák koronavetületének vizsgálatában történt felhasználásra.

A projektív képalkotás klasszikus trigonometria algoritmusával a képpontok valódi helyének számítását végeztem el.

A Hajós-féle viszonykoordinátákkal a távészlelés (remote sensing), például légi fényképezés, rögzített idejü képpontjaiból pontsürítést, azaz további ismeretlen pontok helyét számítottam ki.

Mozgó-, légi- vagy ürjármüről végzett távészlelés ismert koordinátájú úgynevezett illesztőpontjaiból további észlelt pontjainak, mint biológiai objektumoknak, helykoordinátáit számítottam a Hajós-féle viszonykoordinátákkal, majd ezt továbbfejlesztettem időkoordinátákra.

Többváltozós biológiai folyamatokat vizsgáltam viszonykoordinátákkal.

Az agráriumban igen nagyszámú, és rendkívül sokféle információ keletkezik, ezért igen fontos volt az adathalmazok matematikai sajátosságainak megismerése úgy, mint: biológiai kísérletek halmazainak csoportképzése, és ezek izomorfizmusának vizsgálata.

Osztályképzési algoritmusok alkalmazása és újak kidolgozása az agrokémiában. Növényvédelmi adathalmazok osztályképzési lehetőségeinek kombinatorikai vizsgálata.

Növényi betegségek és károsítások megfigyelési adathalmazainak matematikai analízise újabb fogalmak bevezetésével. Az igen nagyszámú, és sokféle információ későbbi kezelhetősége miatt kellett definiálnom az úgynevezett állapotjellemző fogalmát, amely által felvett értéket neveztem a továbbiakban állapotjellemzö-értéknek.

Lényeges kérdésként merült fel az adott pontosság eléréséhez szükséges mintavétel meghatározása, ahol a klasszikus eljárások mellett az adathalmaz természete által előzetesen meghatározott optimális mintavételi arányszámítási módszert dolgoztam ki.

Már meglévő adathalmazok esetén a megbízhatóságot kellett számítanom az ismert matematikai statatisztikai módszerekkel.

Függvényváltozók esetén a klasszikus differenciálszámításra alapozott hibaszámítást alkalmaztam.

A klasszikus valószínűségi változó-, és az újonnan bevezetett állapotjellemző fogalmak megfeleltethetőségét definiáltam a gyakorlatban.

Az amerikai remote sensing módszereket továbbfejlesztve Magyarországon először végeztünk légifelderítést növényi betegségek vizsgálatára.

Japán és orosz biofizikai módszereket tökéletesítve mikromanipulátoros mikroelektródákkal növények és rovarok anyagcseréjét vizsgáltam bioelektromos potenciál eloszlással. Mindkét esetben definiáltam az állapotjellemző értékre alapozott megismerhetőségi korlát és változás fogalmát és kidolgoztam az erre épülő relációs gyorstesztet a növény és rovar anyagcseréjének felderítésére.

Lényeges gyakorlati feladatom volt a környezeti tényezők, mint például a hőmérséklet, nedvességtartalom anyagcserére kifejlett hatásának felderítése, amely miatt definiáltam a hatás fogalmát és felhasználási módszerét. Ezzel lehetővé vált a növényvédőszerek hatásának gyorstesztje a kórokozókra és kártevőkre, valamint a mütrágyák hatásának vizsgálata a növény termésmennyiségére. 
Sajnálatosan jelentős volt a csernobili nukleáris katasztrófát követő radioaktív szennyezettség kimutathatóságával kapcsolatos vizsgálatom az előző gyorsteszttel.

$\mathrm{Az}$ elektromágneses térerősség enzimaktivitásra kifejtett hatásának, illetve gomba- és baktériumtenyészetekre gyakorolt hatásának kimutatására szintén alkalmaztam az előző módszert.

Erdészetben megvizsgálni kívánt erdőállapotok összehasonlításánál használtam kezdeti felvilágosításra relációs gyorstesztet.

Vadgazdálkodásban különböző élőhelyekről származó vadállapotjellemzők, mint például a trófea adatok, tájékoztató összevetését végeztem relációs gyorsteszttel.

A matematikai statisztikai próbákat széleskörüen alkalmaztam. Legtöbbet az adott valószínűségi szinten középérték-összehasonlító t-próbát, illetve szórást összevető F-próbát használtam.

A remote sensing munkáinknál a terepi objektumok és az észlelt terepi objektumok állapotjellemzöit vetettem össze, különös tekintettel a talaj-, a növénytakaró állapotjellemzőire, ami például a növényi betegségek felderítését segítette.

A biofizikai feladatainkban az elektromágneses tér gomba- és baktérium tenyészetekre kifejtett hatásvizsgálatoknál, vagy növényvédőszerek kórokozókra és károkozókra gyakorolt hatásvizsgálatánál széleskörüen alkalmaztam a statisztikai próbákat. A környezeti tényezők növényi kórokozókra és kártevőkre kifejtett hatását is velük mutattam ki. A különböző kemikáliák növényi beltartalom megváltoztatásának kimutatására szintén használtam a statisztikai próbákat. Az erdészeti gyakorlatban különböző erdőművelési eljárások eredményeként előálló erdőállapotokat hasonlítottam össze ezekkel a módszerekkel.

Vadgazdálkodásban különböző élőhelyről származó testméreteket és trófeajellemzőket vetettem össze t- és F-próbákkal.

Az agrárgyakorlatban az egyik legizgalmasabb kérdés a leképezések vizsgálata, a relációk és kapcsolatok felderítése, illetve az összefüggések jellemzőinek meghatározása. A korreláció és regresszió-számítást igen gyakran használtam, amely hasznos gyakorlati eredményeket adott.

A remote sensing folyamán a földi kontroll állapotjellemzők, és a róluk távészleléssel felderített állapotjellemzők közötti kapcsolat-, illetve az összefüggés formájának meghatározását végeztem el, amely lehetővé tette a növényi betegségek és károsítások légifelderítését.

A növényi anyagcsere biofizikai vizsgálatánál különböző mértékü behatások esetén biofizikai paraméterek kapcsolatát mutattam ki.

A növényvédőszerek optimális dózisának meghatározására a gombaölő-, rovarölő- és gyomirtó szerek különböző dózisa és a mortalitás mértéke közötti regressziót számítottam. A klasszikus regresszió-számítást továbbfejlesztettem kontrol szerinti modulációval, illetve intervallumonkénti más számítási formákkal. Több esetben határozott integrálszámítással képzett ív- segédváltozókat felhasználó regresszió-számításom vezetett célhoz. Egyes feladatoknál interpolációs polinomot volt célszerü számítanom.

Az agrokémia nagy kihívása volt a növénytermesztési technológia szaktanácsadása. Meg kellett határozni növényfajonként, sőt növényváltozatonként, sokszor FAO számonként az összes meteorológiai jellemző termésre kifejtett hatását, amelyben regresszió-számításokat használtam. Hasonló feladatot oldottam meg a talaj valamennyi mért állapotjellemzőjének és a növény terméseredményének összefüggés-vizsgálatával, amely szintén nagy tömegü számítási feladatot jelentett.

Erdészetben az úgynevezett fatömegfüggvények az erdő állapotjellemzőinek függvényében adják meg a fatömeget. Meghatározásában numerikus-, analízisbeli-, regressziószámítási- és egyéb módszerekkel magam is részt vettem. 
A légiészleléssel- és ürészleléssel meghatározott paraméterek, és a terepi erdőállapot jellemzők közötti törvényszerü kapcsolatokat regressziós módszerekkel derítettem fel.

Vadgazdálkodásban az élőhely állapotjellemzői és vadállapot jellemzők közötti törvényszerüségeket korrelációs és regressziós módszerekkel vizsgáltam. Az őz- és a szarvas trófea bírálati jellemzők, és az összpontszám közötti kapcsolatot is az előző módszerekkel határoztam meg.

Külső környezeti hatások, valamint speciális kemikáliák növényi és állati anyagcserére gyakorolt hatásának bioelektromos vizsgálatában gyakorta előfordultak szélsőségesen változó mérési állapotjellemző értékek. A haszon- és természetes növények kórokozóinak és károsítóinak felderítésekor a visszavert fény spektrumeloszlásában, valamint az elsődleges detektorokkal észlelt mérési adathalmazban, illetve a másodlagos leképezett információk denzitás vizsgálatában gyakran előfordultak szélsőségesen változó állapotjellemző értékek. Előző halmazok azt a látszatot keltik a hagyományos matematikai vizsgálatokkal, hogy véletlen jellegü törvényszerüség nélküli folyamatokkal állunk szemben, noha pont a káosz maga jellemző az adott jelenségre, s ennek törvényszerüségét sikerült felderítenem. Az ilyen szélsőségesen változó állapotjellemző értékü halmazokat nevezzük fürészfoghalmazoknak, és értékelésükre a lokális szélsőértékek vizsgálatát dolgoztam ki. Ezzel már lehetővé vált számomra a törvényszerüségek felderítése, a hatásmechanizmusok és az agrokémiai gyakorlatban lényeges állapoteltérések jobb megismerése.

Az erdőállapot-jellemzőknek mint a vad élőhelyének légi- és ürfelderítésénél szintén a fürészfoghalmazok lokális szélsőértékeinek törvényszerüségeit vizsgáltam.

A fürészfoghalmazok lokális szélsőértékeinek vizsgálata jó példa egyébként arra is, hogy egyes esetekben mennyire nem szabad, sőt célszerütlen kiegyenlítő matematikai modulokat rákényszeríteni biológiai jelenségekre, hanem ezen biológiai jelenségek belső sajátosságai kell, hogy felépítsék, illetve megfogalmazzák a matematikai törvényszerüséget.

A biomatematikában is rendkívül fontos a képi megjelenítés. Igen kusza hatásmechanizmusokat sikerült úgy tisztázni, hogy képpé alakított metrikus- vagy metrizálható-, illetve nem metrikus információkat keletkezési helyük pontos geodéziai-, vagy helyi geometriai koordinátáival azonosítva együtt, egymáshoz rendelve ábrázoltam. A képi megjelenítés legegyszerübb formái az információkat egy adott szempont szerint ábrázolják, mint például grafikonok, diagramok stb. Az 1962-ben, tizenévesen megjelent bükk-rönkök bütü repedéseinek vizsgálati eredményeit több állapotjellemző szerint csoportosítva grafikusan ábrázoltam, és ezzel térben-, időben- és évgyürüszerkezetben tettem láthatóvá a mért értékeket.

Jelentős feladat volt a talaj-elemtartalom-, a növények elembeltartalma-, időjárási tényezők értékeinek eloszlását mutató számítógépes tematikus térképeknek együttes geodéziai hozzárendelését végeztem el a haszonnövények terméseredményeihez, ami igen nagy segítséget adott a gyakorlati növénytermesztésnek.

$\mathrm{Az}$ erdészetben hasonlóan elvégeztem a tematikus térképek kölcsönösen egyértelmü geodéziai egymáshoz rendelését, ami nagy segítséget adott a fafaj-megválasztáshoz.

A vadgazdálkodásban a talaj-, a növénytermesztési-, erdészeti- és meteorológiai vadállománybéli állapotjellemzőket geodéziailag kölcsönösen egyértelmüen egymáshoz rendelve kaptam meg az egyes vadfajok élöhelyének minőségi kategóriáit. Megjegyzendő, hogy hazánkban az agráriumban készültek el az ország első tematikus számítógépes térképei az 1970-es évek közepén.

Az elvégzett vizsgálatok egyik alapkérdése volt, hogy milyen állapotjellemzőket vegyünk figyelembe, és azokat miként rendeljük egymáshoz. Sok esetben szakmai ismereteink vagy gyakorlati tapasztalatunk alapján választjuk ki és rendeljük egymáshoz az állapotjellemzőket, és azok értékeit. 
Rovarokon végzett bioeletromospotenciál vizsgálataimnál viszont találkoztam olyan információátvitellel, amelynek tényét kísérletileg lehetett igazolni, viszont megnyilvánulásának módját vagy müködését nem. A jelenséget több élőszervezeten is megfigyelve Black Bear Effect-nek, azaz BBE-nek neveztem el.

Biofizikai és remote sensing vizsgálataim szükségessé tették, hogy bevezessem az állapotjellemző értékek mellett a relációk, valamint a relációk sajátosságai fogalmakat, illetve mind ezek együttesével a természeti jelenség definiálását. A már említett biofizikai és remote sensing vizsgálataim alapján el kellett különíteni a valóban létező természeti jelenséget (amelyet konkrétan észlelni tudunk), valamint az ember számára elképzelhető természeti jelenséget (megfigyelhető és meg nem figyelhetö), és fel kell tételeznünk elképzelhetetlen természeti jelenséget, amiről semmit nem tudunk pillanatnyilag, bár ettől még lehet, hogy tőlünk függetlenül létezik.

A múltban, jelenben illetve jövőben valóban létező, valamint elképzelhető és elképzelhetetlen természeti jelenségek összességének matematikai konstrukciójával definiáltam az univerzumot, amelyek összességéből tovább képezhető a multiverzum. Speciális konstrukció számunkra a black hole (BH) feketelyuk, amely elképzelhető, de ismeretlen, valamint elképzelhetetlen konstrukciókból tevődik össze.

Az előző, látszólag felesleges matematikai konstrukcióknak viszont nagy jelentősége van egy-egy igen nagy és összetett adatbázist igénylő gyakorlati feladat megoldásánál.

Az igazán nagy jelentőségü gyakorlati agrofeladatok megoldásánál minden esetben igen nagy adatbázist kellett létrehozni, sok esetben több, már meglévő adatbázist kellett egymáshoz rendelni és kiegészíteni.

Szép és nagy, több adatbázist igénylő feladat volt számomra a növénytermesztési mütrágya-szaktanácsadás rendszerének elkészítése. Gondoskodni kellett a meteorológiai-, talajtani-, technológiai-, haszonnövényi adatbázisok kölcsönösen egyértelmü egymáshoz rendeléséröl. Ki kellett dolgoznom az igen nagyszámú metrikus és metrikátlan, valamint eltérő vonatkozási alapú állapotjellemzők értékeit kezelni tudó olyan matematikai modellt, amely egyrészt ki tudja számolni, hogy a kérdezett szántóföldi táblán mekkora termés várható, vagy másrészt az adott szántóföldi táblán egy adott növény kívánt terméseredményét milyen technológiával mennyi nitrogén-, foszfor-, kálium mütrágyával érhetjük el. Továbbá gondoskodni kellett a szaktanácsadási rendszer alkalmazásával nyert új növénytermesztési adatok visszacsatolásáról. Erre dolgoztam ki 1970-es évek közepén az úgynevezett PMSB matematikai modellt, amely azóta az élet szinte minden területén az orvostudománytól a technikáig elterjedt. A feladat megoldásában terepen dolgozó gyakorlati szakemberek-, laboratóriumokban munkálkodók és számítástechnikusok sokasága vett részt. Nagyságrendileg több száz szakember segítette a feladat megoldását. Az Országos Tervhivatal Számítástechnikai Központjának ICL nagy gépén és az országos agrokémiai vidéki hálózat termináljain a rendszer gyönyörüen működött, de sajnos a növénytermesztési közösségek (állami gazdaságok, szövetkezetek) birtokviszonyai felbomlottak, és munkaszervezeti egységeik s az adatbázisok széthullottak. Szerencsére viszont maga a PMSB matematikai modell tovább szárnyalt és nagy nemzetközi érdeklődést váltott ki.

Ugyancsak nagy és több adatbázist igényelt az általam tervezett és irányított egyik legszebb modellezési erdészeti feladat, az úgynevezett hosszútávú országos erdőállomány véghasználati hozamszabályozás, amely arra ad feleletet, hogy Magyarország területén a többszázezer erdőrészletben az 50 év alatt hol, mikor, mennyi fát kell kivágni. A feladat adatbázis kezelésből-, erdőállapot időfüggvényeinek modellezéséből-, kiegyenlítésből-, terepi végrehajtás eredményeinek visszacsatolásából- és ellenőrzésből állt. Számítógépes hozamszabályozást az országban elsőként végeztük. Az országos hozamszabályozás kötelezettsége az 1996-os erdőtörvénybe is bekerült. Hozamszabályozás közvetve kimutatta a rablógazdálkodást, amely miatt engem, mint a módszer kidolgozóját, irányító végrehajtóját, 
felelösét és az eredmények ismertetőjét hosszú fegyelmi eljárás alá vontak, amit aztán a valós tények miatt kénytelenek voltak teljesen visszavonni. Sajnos a mostani erdőtörvényből kivették az országos hozamszabályozás kötelezettségét, csupán a hozamvizsgálatot írják elő. Ez a tény késztetett a lokális optimumok és az abszolút optimum viszonyának vizsgálatára.

A kivágott fa legkedvezőbb felhasználását pedig példaként Zala területére optimalizálási feladatként oldottam meg klasszikus lineáris programozással.

A vadgazdálkodásban a meteorológiai-, növénytermesztési-, erdészeti- és vadgazdálkodási adatbázist kölcsönösen egyértelmüen egymáshoz rendelve határoztam meg a legfontosabb törvényszerüségeket. Sajnos több esetben rablógazdálkodást derítettem fel, viszont örömteli, hogy a magyar élőhelyi adottságok a számításaim szerint lehetővé teszik a 300 IC pontos trófeájú gímszarvas életét. Az előre kiszámított adatot rá pár évre igazolta a vadászati gyakorlat, amely 10\%-on belüli agancsú szarvasbikát hozott terítékre.

\section{Utóirat}

Az agronómiában a növénytermesztési-, agrokémiai-, erdészeti- és vadgazdálkodási feladatok biofizikai- és remote sensing (távészlelés) módszerekkel kiegészített biomatematikai megoldásai kiváltották elébb az amerikai űrkutatás NASA, és az amerikai akadémiai szolgálat, valamint a szovjet Interkozmos élénk érdeklődését.

\section{4. Összefoglaló}

A biomatematika egyrészt matematikai módszerekkel modellezi a biológiai jelenségeket, másrészt a biológiai jelenségek önmaguk határozzák meg a matematikai konstrukciókat. Biomatematikai módszerekkel 1960-tól erdészeti-, növénytermesztési- és vadgazdálkodási gyakorlati feladatokat oldottam meg az agráriumban. Kiemelt feladatom volt az erdöállapotjellemzők közötti összefüggés-vizsgálat és a hozamszabályozás, valamint a kémiai-, meteorológiai- és talajtani állapotjellemzők hatásvizsgálata a kultúrnövényekre, illetve a mezőgazdasági-, erdészeti- $\mathrm{s}$ vadgazdálkodási állapotjellemzők közötti törvényszerüségek felderítése. A biomatematika alkalmazása napjainkra az agrárium szinte minden területén széleskörüen elterjedt, ami a benne rejlö nagy gyakorlati lehetöségek miatt az ugrásszerúen megnövekedett felhasználói igényeknek és a számítástechnika rohamos fejlődésének köszönhető. Ennek a hatalmas munkának pirinyó töredékében vettem részt fél évszázadon keresztül, hogy megoldjam az agráriumban rám eső gyakorlati és elméleti feladatokat.. Mára már olyan szakterületek is megjelentek, mint a biokibernetika, bionika és bioinformatika, amelyek a jövőben még nagyobb reményekre jogosítanak.

\section{Irodalomjegyzék}

[1] Smith, C. A. B., Biomathematics, the principles of mathematics for students of biological science. London, 1954, Charles Griffin and Comp. Ltd.

[2] Bán, I., "Bükk rönkök bütü repedéseinek vizsgálata", Erdőgazdaság és Faipar 1962. 4. szám.

[3] Bán, I.,"A matematika és a biológia határán", Természet Világa (Természettudományi Közlöny), 1970. 5. szám.

[4] Bán, I., Biomathematics and its Application in Plant Cultivation, Akadémiai Kiadó, Budapest, 1987. p. 202.

[5] Bán, I., Biomathematics and its Application in Plant Cultivation, Elsevier, Amsterdam-Oxford-NewYorkTokyo, 1988. p. 202.

[6] Bán, I., Vezetői döntések előkészítése halmazok leképezésével a mező- és erdőgazdaságban, Akadémiai Kiadó, Budapest, 1987. p. 326. 